\title{
Molecular characterization and virulence of fungal isolates against the bean flower thrips, Megalurothrips usitatus Bagnall (Thysanoptera: Thripidae)
}

\author{
Bo Yang, Cailian Du, Shaukat Ali and Jianhui Wu
}

\begin{abstract}
The bean flower thrips, Megalurothrips usitatus Bagnall (Thysanoptera: Thripidae) is a major pest of leguminous crops grown in Southern China. This study reports the isolation, identification (through molecular characterization) and pathogenic potential of 6 fungal isolates belonging to different fungal species. The fungi were isolated from soil samples collected from different areas of Southern China and were identified as Beauveria bassiana (3 isolates; SB010, SB009, SP016), Cordyceps fumosorosea (one isolate; SP535), Akanthomyces attenuatus (one isolate; SCAUDCL53), and Aspergillus nomius (one isolate; SCAUN-1). Conidial suspension $\left(1 \times 10^{8}\right.$ conidia mll $\left.{ }^{-1}\right)$, and the crude extract $\left(0.4 \mathrm{mg} \mathrm{ml}^{-1}\right)$ of all the 6 fungal isolates were tested for their pathogenicity against M. usitatus adults. The results showed that $A$. attenuatus (SCAUDCL-53) and B. bassiana (SB010) were the most effective fungal isolates against $M$. usitatus out of all the isolates used in this study. At 5 days post-inoculation, conidial suspension of $A$. attenuatus (SCAUDCL-53) and B. bassiana (isolate SB010) caused 100 and 90\% mortality rates, respectively. The median lethal time ( $\left(\mathrm{T}_{50}\right)$ values of fungal isolates SCAUDCL-53, SB010, SB009, SP016, SP535, and SCAUN-1against M. usitatus adults were $1.36,3.79,6.51,8.49,17.36$, and 5.01 days, respectively. The application of crude fungal extracts of SCAUDCL-53, SB010, SB009, SP016, SP535, and SCAUN-1 against the pest resulted in 85, 93.3, 56.7, 33.3, 41.7, and $53.75 \%$ mortality rates, respectively after 5 days of application. Respective $L T_{50}$ values of the crude fungal extracts against M. usitatus were $3.37,2.85,4.87,7.13,6.43$, and 4.64 days. The fungal isolates used in this study showed considerable bioactivity against the M. usitatus and can be used as potential natural pest control agent for the ecofriendly management of M. usitatus.
\end{abstract}

Keywords: Megalurothrips usitatus, Entomopathogenic fungi, Biological control, Virulence, Molecular characterization

\section{Background}

The bean flower thrips, Megalurothrips usitatus Bagnall (Thysanoptera: Thripidae), is a major pest of cowpea causing considerable economic losses to this crop by damaging cow pea leaves, flowers and pods (Mound and Walker, 1987). M. usitatus damage can cause leaf wrinkling, growth point atrophy, pod scab, and other effects

\footnotetext{
* Correspondence: aliscau@scau.edu.cn; jhw@scau.edu.cn

Key Laboratory of Bio-pesticide Innovation and Application of Guangdong Province, Department of Entomology, South China Agricultural University, Guangzhou 510642, People's Republic of China
}

on cowpea plant reducing the market value of crop (Tang et al. 2015). The flowering stage is known to be the most vulnerable to $M$. usitatus attack and hundreds of $M$. sitatus (nymphs or adults) can be seen per flower during peak pest ultimately leading to reduced yield through premature flower loss (Tang et al. 2015). Currently, chemical insecticides are being used as the principal control agent against $M$. usitatus. They are not effective enough due to the cryptic habits of $M$. usitatus (such as staying within flowers and their short life cycles) (Tang et al. 2015). The injudicious use of chemical

\section{Springer Open}

(0) The Author(s). 2020 Open Access This article is licensed under a Creative Commons Attribution 4.0 International License, which permits use, sharing, adaptation, distribution and reproduction in any medium or format, as long as you give appropriate credit to the original author(s) and the source, provide a link to the Creative Commons licence, and indicate if changes were made. The images or other third party material in this article are included in the article's Creative Commons licence, unless indicated otherwise in a credit line to the material. If material is not included in the article's Creative Commons licence and your intended use is not permitted by statutory regulation or exceeds the permitted use, you will need to obtain permission directly from the copyright holder. To view a copy of this licence, visit http://creativecommons.org/licenses/by/4.0/. 
insecticides has resulted in development of insecticide resistance in M. usitatus (Immaraju et al. 1992). Therefore, the development of ecologically sound and sustainable control measures for $M$. usitatus management is required on urgent basis (Elimem et al. 2018).

Entomopathogenic fungi (EPF) have received considerable attention as biological control agents of thrips and several studies have demonstrated the effectiveness of them (such as Beauveria bassiana, Metarhizium anisopliae, Paecilomyces fumosoroseus, A. attenuatus, Aschersonia aleyrodis) against different thrips species (Skinner et al. 2012 and Wright et al., 2016). Ugine et al. (2006) reported that application of $B$. bassiana significantly reduced Frankliniella occidentalis populations by $81 \%$, especially at the flowering stage of crops. The Verticillium lecanii (V3450, Vp28) is a well-known species of EPF against thrips and some isolates of this species are being developed as commercial biopesticides (Ainsworth et al., 2008).

The potential use of B. bassiana, C. fumosorosea, and $A$. attenuates have been demonstrated on many insect pests (Ali et al. 2018 and Zimmermann 2018). And the insecticidal attribute of $B$. bassiana and $V$. lecanii developed its use in biopesticide industry (Singh et al. 2015). Isaria fumosorosea is mainly used to control agricultural pests such as Bemisia tabaci, aphids and thrips. A. nomiu is a facultative pathogen of many plants and animals (St Leger et al., 2000).

The present study was designed to isolate, identify, and describe different strains. The fungal conidia and crude extract were also tested for their pathogenicity against $M$. usitatus.

\section{Materials and methods}

\section{Sample collection and fungal isolation}

The soil samples were collected from farmers' fields from 6 localities (Yunan, Hunan, Guangxi, Guangdong, Fujian and Hainan) of Southern China. Fungal isolation was carried out following the method described by Gottel et al. (2008) and Imoulan et al. (2011). Briefly, $3 \mathrm{~g}$ soil sample was added to $30 \mathrm{ml}$ of $\mathrm{ddH}_{2} \mathrm{O}$ containing $0.05 \%$ Tween 80 . The mixture was vortexed for $15 \mathrm{~min}$ and 1 $\mathrm{ml}$ suspension was layered onto potato dextrose agar (PDA) plates. The plates were incubated at $26 \pm 6{ }^{\circ} \mathrm{C}, 70$ $\pm 5 \% \mathrm{RH}$ and 16:8 $\mathrm{h}$ L:D photoperiod for 7 days. The growth of the fungi was observed after 7 days and were re-inoculated by inoculation of individual fungus on new PDA plates. In this way, several rounds of inoculation were performed until a purified strain based on the phenotypic properties and fungal morphology was obtained (Saito and Brownbrideg, 2016 and Du et al. 2019)

\section{DNA extraction, PCR amplification, and construction of phylogenetic trees}

Genomic DNA of fungal isolates, purified after the isolation process, was extracted by using a fungal genomic DNA extraction kit supplied by Ezup, Sangon Biotech, Shanghai, China Internal transcribed spacer region (ITS) of fungal DNA was amplified in order to identify the species of each strain (Imoulan et al. 2016). The reaction mixture for PCR amplification consisted of $25 \mu \mathrm{l} 2 \times$ TapPCR Master Mix, $1 \mu \mathrm{l}$ of each primer $(10 \mu \mathrm{M}), 1 \mu \mathrm{l}$

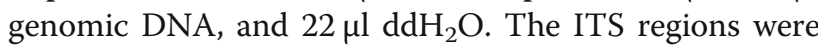
amplified using the primers (Table 1). The thermal profile of the PCR condition for primer included an initial denaturation at $94{ }^{\circ} \mathrm{C}$ for $5 \mathrm{~min}$, followed by 35 cycles with a new denaturation at $94^{\circ} \mathrm{C}$ for $30 \mathrm{~s}$, annealing at $53^{\circ} \mathrm{C}$ for $30 \mathrm{~s}$, extension at $72^{\circ} \mathrm{C}$ for $1 \mathrm{~min}$, and with a final extension of $10 \mathrm{~min}$ at $72^{\circ} \mathrm{C}$. The PCR products were assayed for fragment size by agarose gel electrophoresis. Then, the PCR products were sent to the Shanghai Majorbio Bio-pharm Technology (Shanghai, China) for sequence analysis. The obtained ITS gene sequences of all strains were sequence-spliced with Genious version 7.1.4 (Goloboff and Catalano, 2016), then aligned in National center for biotechnology information (NCBI), the aligned sequences were downloaded, and then all sequences were constructed with MEGA Version 7.0 to construct a maximum likelihood (ML) tree (Kumar et al. 2016).

\section{Virulence of the fungi in the laboratory Insect colony}

Adults of M. usitatus were collected from a cowpea field at South China Agricultural University, Guangzhou, China during 2017. The collected insects were subsequently reared under laboratory conditions by the bean pod method (Espinosa et al. 2005). The insect colonies were kept at $26 \pm 6{ }^{\circ} \mathrm{C}, 70 \pm 5 \% \mathrm{RH}$ and 16:8 h L:D photoperiod in a climate control chamber. Newly emerged adult females were used for fungal bioassay studies.

\section{Fungus culture, conidia suspension, and crude extract preparation}

The tested strains (SCAUDCL-53, SP016, SP535, SB009, SB010, and SCAUN-1) were cultured on PDA plates for 7 days under laboratory conditions. Conidia were

Table 1 Primers used in this study

\begin{tabular}{llll}
\hline Sr No. & Genes & Primer & Primer Sequence \\
\hline 1 & ITS & ITS4F & TCCTCCGCTTATTGATATGC \\
& & ITS5R & GGAAGTAAAAGTCGTAACAAGG
\end{tabular}




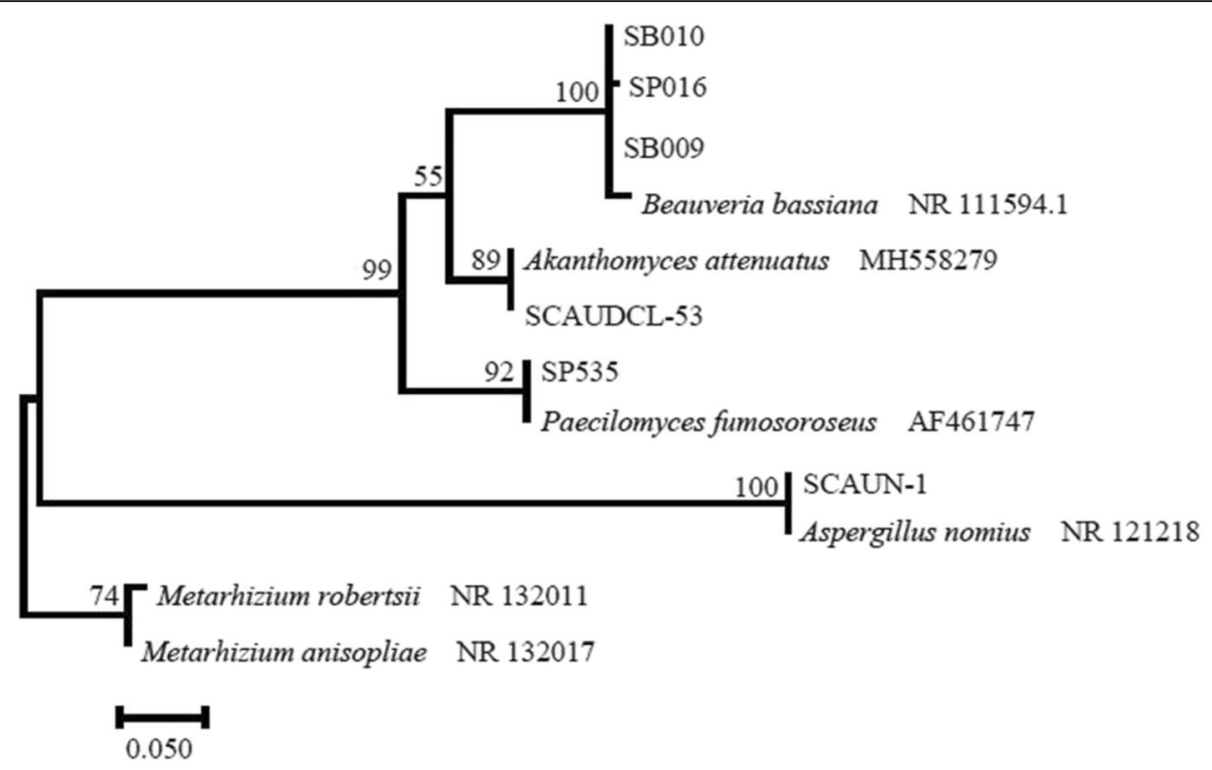

Fig. 1 Majority rule consensus phylogram from the maximum likelihood (ML) tree based on the sequences of the ITS region for six strains (SB009, SB010, SP016, SP535, SCAUDCL-53, and SCAUN-1). Metarhizium robertsii and Metarhizium anisopliae were used as an outgroup

harvested from culture plates by scraping the surface of the mycelia with sterile cell scrapers into sterile deionized water containing $0.05 \%$ Tween-80. The conidia were counted under compound microscope (Ningbo Shunning Instruments Co. Ltd) at $\times 40$ magnification by using hemocytometer (Qian Yihua Glass Instruments Co. Ltd.) to calibrate a concentration of $1 \times 10^{8}$ conidia $\mathrm{ml}^{-1}$. Freshly prepared conidial suspensions were used for all experiments.

Fifty milliliters of freshly prepared sabouraud dextrose broth medium (SDB) was added to 250-ml Erlenmeyer flasks followed by sterilization at $121^{\circ} \mathrm{C}$ for $30 \mathrm{~min}$. Five milliliters of freshly prepared fungal suspension $\left(1 \times 10^{7}\right.$ conidia $\mathrm{ml}^{-1}$ ) of different fungal isolates was added to culture medium. The flasks were incubated in a rotary shaker at $120 \mathrm{rpm}, 28^{\circ} \mathrm{C}$ for 5 days. After 5 days, fungal cultures were filtered through Whatman filter paper (Qian Yihua Glass Instruments Co. Ltd) to obtain the supernatant for subsequent studies. The protein concentrations of crude extracts were quantified by using bouvine albumin serum as substrate (Bradford 1976). The protein concentration of all the crude extracts was adjusted to $0.4 \mathrm{mg} \mathrm{mL}^{-1}$ by following Quesada et al. (2006).

\section{Bioassay method}

Laboratory bioassays were conducted to evaluate the toxicity of different fungal isolates identified during this study against the $M$. usitatus adults by using centrifuge tube residual bioassay ( $\mathrm{Du}$ et al. 2019). The centrifuge tubes (9 $\mathrm{ml})$ and bean pods $(1 \mathrm{~cm})$ were immersed in conidial suspension $\left(1 \times 10^{8}\right.$ conidia $\left.\mathrm{ml}^{-1}\right)$ and crude extract for $2 \mathrm{~h}$, followed by drying under sterilized conditions. The centrifuge tubes and bean pods treated with $\mathrm{ddH}_{2} \mathrm{O}$ having $0.05 \%$ Tween- 80 served as control. After drying, adult females of $M$. usitatus (100 individuals) were transferred to the tubes having bean pods treated with same fungal treatment. Each centrifuge tube was sealed with a cotton plug to prevent thrips from escaping. The whole experiment was repeated thrice with fresh batches of insects at $26 \pm 1{ }^{\circ} \mathrm{C}, 75 \% \mathrm{RH}$, and 16:8 L:D photoperiod. The insects were observed on daily basis to record the mortality data following Du et al. (2019).

\section{Microscopic examination}

Newly emerged $M$. usitatus adults were inoculated by the conidial suspension $\left(1 \times 10^{8}\right.$ conidia $\left.\mathrm{mL}^{-1}\right)$ and the crude protein extract $\left(0.4 \mathrm{mg} \mathrm{ml}^{-1}\right)$ of all the 6 fungal isolates and were incubated at $25^{\circ} \mathrm{C}$ and $75 \% \mathrm{RH}$ in the dark. The infected $M$. usitatus (5 individuals) were sampled at 1, 2, 3, 4, and 5 days after inoculation. Gross changes in the appearance of the infected $M$. usitatus were directly monitored at different times after inoculation under a D850 camera (Nikon Co. Ltd. Japan).

Table 2 Reference entomopathogenic fungi from GeneBank used for the phylogenetic analysis

\begin{tabular}{ll}
\hline Species & Accession Number \\
\hline Beauveria bassiana & NR_111594 \\
Cordyceps fumosorosea & AF461747 \\
Aspergillus nomius & NR_121218 \\
Akanthomyces attenuatus & MH558279 \\
Metarhizium robertsii & NR_132011 \\
Metarhizium anisopliae & NR_132017 \\
\hline
\end{tabular}



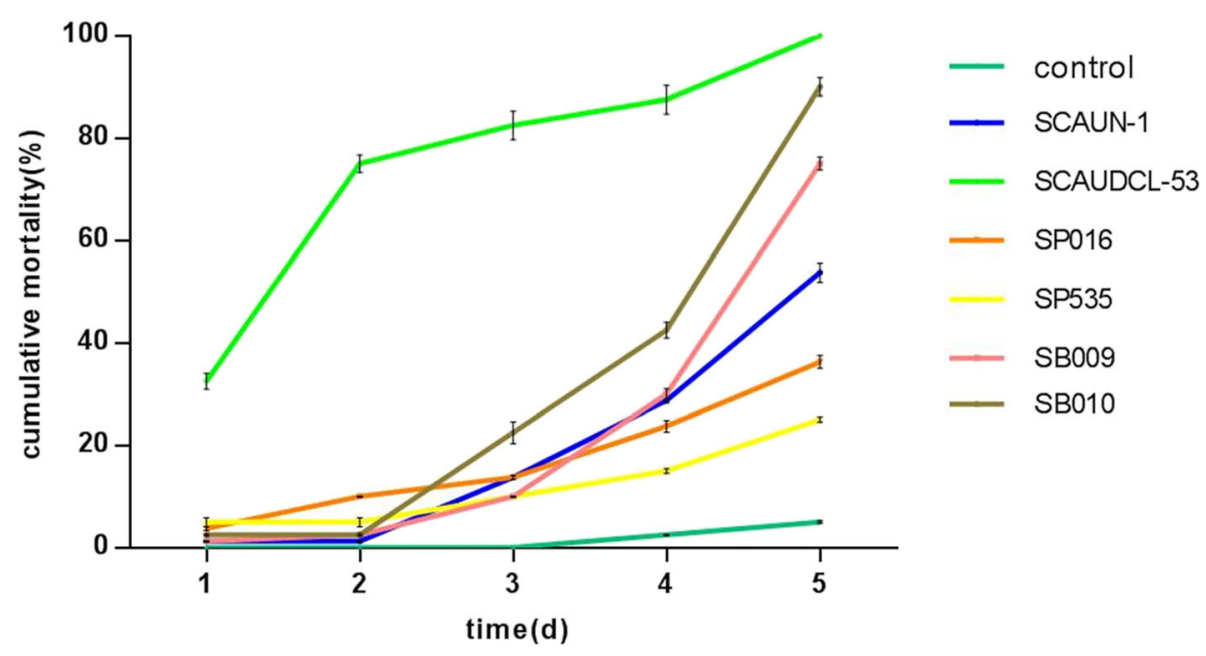

Fig. 2 Corrected mortality rates of Megalurothrips usitatus with different time of conidial suspensions

\section{Statistical analysis}

Mortality data were percent transformed and were subjected to probit analysis. All the analysis were performed through SAS software v9.1 (SAS et al., 2000).

\section{Results and discussion}

\section{Identification of the fungi}

The present study reported 6 fungal isolates belonging to 4 fungal species from isolated soil samples collected from different localities of southern China. The result showed that the strains SB009, SB010, and SP016 were identified as B. bassiana (NR_111594). Strain SP535 was identified as C. fumosorosea (AF461747). Strain SCADDCL-53 was consistent with the A. attenuatus; MH558279 and isolate SCAUN-1 was identified as A. nomius (NR_121218) (Fig. 1).
The identification of entomopathogenic fungi, based on morphological features, can lead to ambiguous results (Ziółkowska et al. 2015). Nucleic acid sequence analysis is commonly used method for the identification and classification of fungi (Funk et al. 1983). It compares the correlation between homologous molecules by determining the composition of nucleotide sequences in the primary structure of nucleic acid (Diaz et al. 2012). Sequencing of the ITS region of rRNA is currently regarded as the standard method for phylogenetic analyses and identification of fungal species (Schmidt and Moreth, 2002; Cafarchia et al. 2013 and Kawasaki 2011) (Table 2). In this study, the comparison of ITS sequences of the isolated fungi showed that they were closely related to B. bassiana (isolates SB009, SB010, SP016), C. fumosorosea (isolate SP535), A. attenuatus (isolate SCAUDCL-1), and $A$. nomius (isolate SCAUN-1).

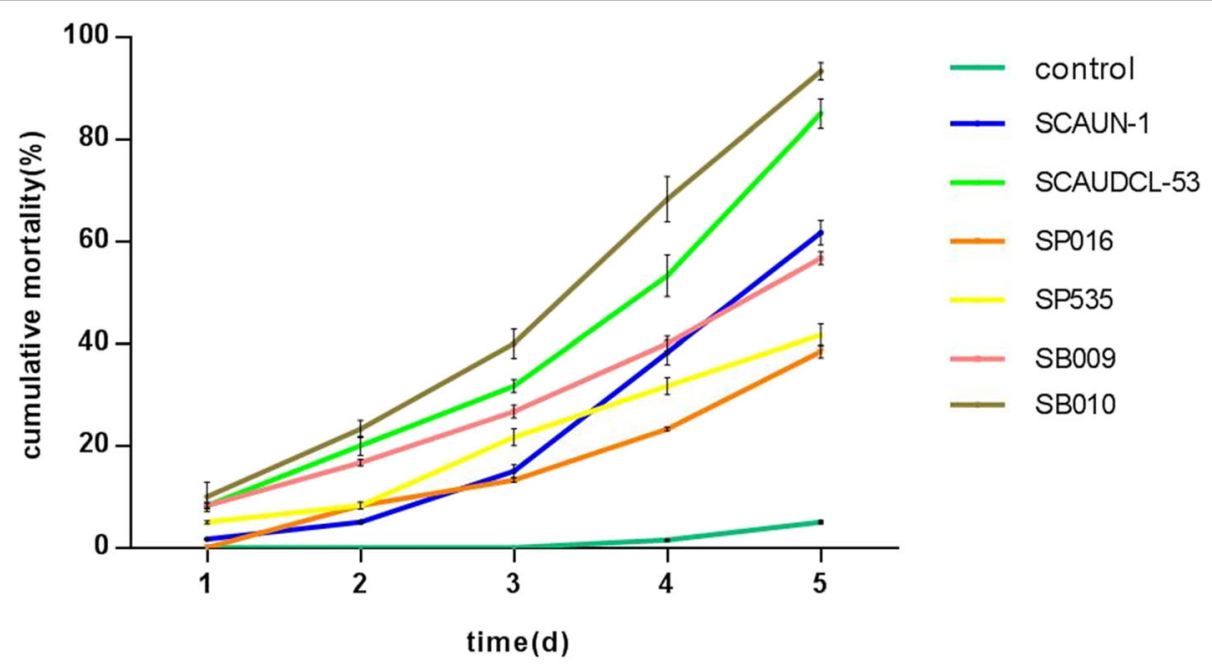

Fig. 3 Corrected mortality rates of Megalurothrips usitatus with different time of crude protein extract 
Table $3 \mathrm{LT}_{50}$ values for fungal strains against Megalurothrips usitatus adults $\left(1 \times 10^{8}\right.$ conidia $\left.\mathrm{ml}^{-1}\right)$

\begin{tabular}{lllll}
\hline Strain & & Toxicity regression equations & $\mathrm{LT}_{50}$ (day) & 95\% confidence limit \\
\hline B. bassiana & SB009 & $Y=2.98 X-6.54$ & $6.51 \pm 0.33^{\mathrm{c}}$ & $(4.75-12.05)$ \\
& SB010 & $Y=5.44 X-10.66$ & $3.79 \pm 0.58^{\mathrm{d}}$ & $(3.50-5.88)$ \\
& SP016 & $Y=2.04 X-4.71$ & $8.49 \pm 0.24^{\mathrm{b}}$ & $(5.18-9.69)$ \\
C. fumosorosea & SP535 & $Y=1.53 X-3.99$ & $17.26 \pm 1.98^{\mathrm{a}}$ & $(12.43-28.31)$ \\
A. attenuatus & SCAUDCL-53 & $Y=3.12 X-4.72$ & $1.36 \pm 0.11^{\mathrm{d}}$ & $(0.89-1.73)$ \\
A. nomius & SCAUN-1 & $Y=4.76 X-9.91$ & $5.01 \pm 0.43^{\mathrm{cd}}$ & $(4.23-7.09)$ \\
\hline
\end{tabular}

Different superscript lowercase letters in the same column indicate significant differences at $5 \%$ level of significance

Virulence of the fungi in the laboratory and greenhouse Analysis of mortality data showed that B. bassiana isolate SB010 was the most effective fungal isolate (except A. attenuatus isolate SCAUDCL-53) against $M$. usitatus adults when compared with other isolates used in this study as conidial suspension. The crude extract of this isolate caused 90 and $93.3 \%$ mortality rates of $M$. usitatus adults (Figs. 2 and 3). The conidial suspension of SCAUDCL-53 strain showed highest mortality rate (100\%), whereas lowest mortality (25\%) was observed for conidial suspension of SP535. The probit analysis of the pathogenicity data revealed significantly lower $\mathrm{LT}_{50}$ values for conidial suspension as well as crude protein extracts of $A$. attenuatus isolate SCAUDCL-53 and $B$. bassiana isolate SB010 than other isolates used in this study (Tables 3 and 4). The lowest $\mathrm{LT}_{50}$ value of conidial suspension (1.36 days) was observed for A. attenuatus isolate SCAUDCL-53, while in case of crude protein extract the lowest $\mathrm{LT}_{50}$ was observed for B. bassiana isolate SB010 with a mean value of $2.85 \pm 0.16$ days. Significant differences in the pathogenicity of different fungal isolates against $M$. usitatus were observed during this study. The conidial suspension $\left(1 \times 10^{8}\right.$ conidia $\mathrm{ml}^{-1}$ ) of $A$. attenuatus isolate SCAUDCL-53 was proved to be the most virulent showing (100\%) mortality of $M$. usitaus after 5 days of application.

Several investigations have reported the susceptibility of different thrips species to EPFs. Ravensberg et al. (1990) reported that sprayings $V$. lecanii at weekly intervals reduced the F. occidentalis incidence by $90 \%$. Wang (2012) screened out different isolates of Lecanicillium lecanii for the management of Gynaikthrips ficorum and showed more than $(85.56 \%)$ mortality of G. ficorum by L. lecanii isolateV16063. The $\mathrm{LT}_{50}$ values (1.36 days) of $A$. attenuatus isolate SCAUDCL-53 against $M$. usitaus at a concentration of $1 \times 10^{8}$ conidia $\mathrm{mL}^{-1}$ observed during this study are a little lower than those observed by Du et al. (2019) who observed $\mathrm{LT}_{50}$ of 3.5 days for $A$. attenuatus isolate SCAUDCL-38. B. bassiana is known as an effective biological control agent of several insect species (Rezende et al. 2009). We observed high pathogenicity of B. bassiana (SB010) towards M. usitaus under laboratory conditions, suggesting that it has high capacity in M. usitaus control. In the current study, conidial suspension $\left(1 \times 10^{8}\right.$ conidia $\mathrm{mL}^{-1}$ ) of B. bassiana isolate SB010 exhibited $90 \%$ mortality of $M$. usitaus after 5 days of fungal application whereas the median lethal time $\left(\mathrm{LT}_{50}\right)$ of conidial suspension was 3.79 days. However, the isolates SB009 and SP016 of B. bassiana just inhibited $36.25 \%$ and $36.21 \%$ of M. usitaus. Jacobson et al. (2001) reported that B. bassiana showed remarkable pathogenicity on F. occidentalis and reported $87 \%$ mortality. The differences in the values of mortality compared to those obtained in the present study could be explained by the different $B$. bassiana species and experimental insects hosts (Jacobson et al., 2001). At present, I. fumosorosea is mainly used to control agricultural pests such as whiteflies, aphids, and thrips (Faria and Wraight, 2007; Kabaluk and Gazdik, 2005). In this study, M. usitaus were less susceptible to the strain SP535 isolated of C. fumosorosea, showing 25\% mortality.

Although fungal conidia are commonly used to control insect pests, this application method has limitation as

Table $4 \mathrm{LT}_{50}$ values for fungal crude extracts against Megalurothrips usitatus adults $\left(0.4 \mathrm{mg} \mathrm{m}^{-1}\right)$

\begin{tabular}{lllll}
\hline Strain & & Toxicity regression equations & $\mathrm{LT}_{50}$ (day) & 95\% confidence limit \\
\hline B. bassiana & SB009 & $Y=2.29 X-4.73$ & $4.87 \pm 0.22^{\mathrm{b}}$ & $(3.63-10.21)$ \\
& SB010 & $Y=3.68 X-6.77$ & $2.85 \pm 0.16^{\mathrm{c}}$ & $(2.38-3.47)$ \\
& SP016 & $Y=2.86 X-6.39$ & $7.13 \pm 0.65^{\mathrm{a}}$ & $(4.99-9.37)$ \\
C. fumosorosea & SP535 & $Y=2.31 X-5.05$ & $6.43 \pm 0.17^{\mathrm{a}}$ & $(4.48-11.58)$ \\
A. attenuatus & SCAUDCL-53 & $Y=3.35 X-6.39$ & $3.37 \pm 0.39^{\mathrm{bc}}$ & $(2.78-4.28)$ \\
A. nomius & SCAUN-1 & $Y=4.18 X-8.56$ & $4.64 \pm 0.28^{\mathrm{b}}$ & $(3.89-6.51)$ \\
\hline
\end{tabular}

Different superscript lowercase letters in the same column indicate significant differences at $5 \%$ level of significance 


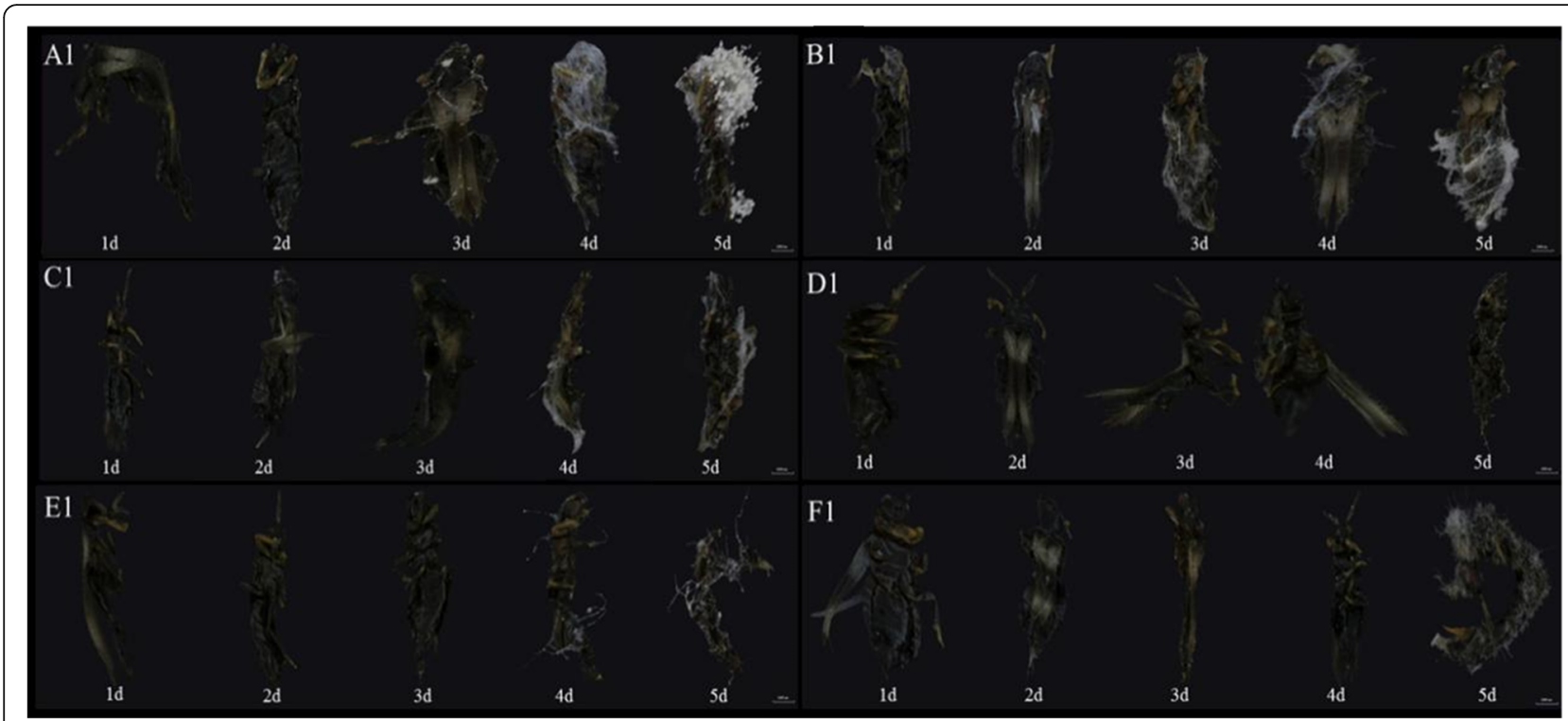

Fig. 4 Images of Megalurothrips usitatus infected with conidia suspension and observed through a dissecting microscope. A1-F1 Infected Megalurothrips usitatusat SB009, SB010, SP016, SP535, SCAUDCL-53, and SCAUN-1, respectively

fungal conidia can be susceptible to environmental conditions (Skinner et al. 2012; Rangel et al. 2008). The current study also examined the biological activities of crude fungal protein extracts. In the current study, crude extracts of all the six fungal isolates (used at $0.4 \mathrm{mg} \mathrm{mL}^{-1}$ protein concentrations of crude extract) showed significantly different rates of $M$. usitaus mortality. The crude extracts of B. bassiana isolate $\mathrm{SB} 010$ was the most virulent showing 93.3\% mortality of $M$. usitaus after 5 days of application. Previous studies have reported similar dose-dependent insecticidal effects of fungal secondary metabolites against different insect species. Muzammil and Shoaib (2018) reported that $10 \mathrm{mg}$ protein $/ \mathrm{ml}$ concentration of crude $B$. bassiana (isolate Bb-01) extract showed (91\%) mortality on Musca domestica L. (Diptera: Muscidae). The other major impediment in the development of fungal insecticides is the time required to control an insect pest ( $\mathrm{St}$ Leger and Screen, 2001). The concentration of crude B. bassiana extract used in the present experiments was much lower than those used by Muzammil and Shoaib (2018) which confirmed the higher pathogenic potential of B. bassiana isolate SB010.

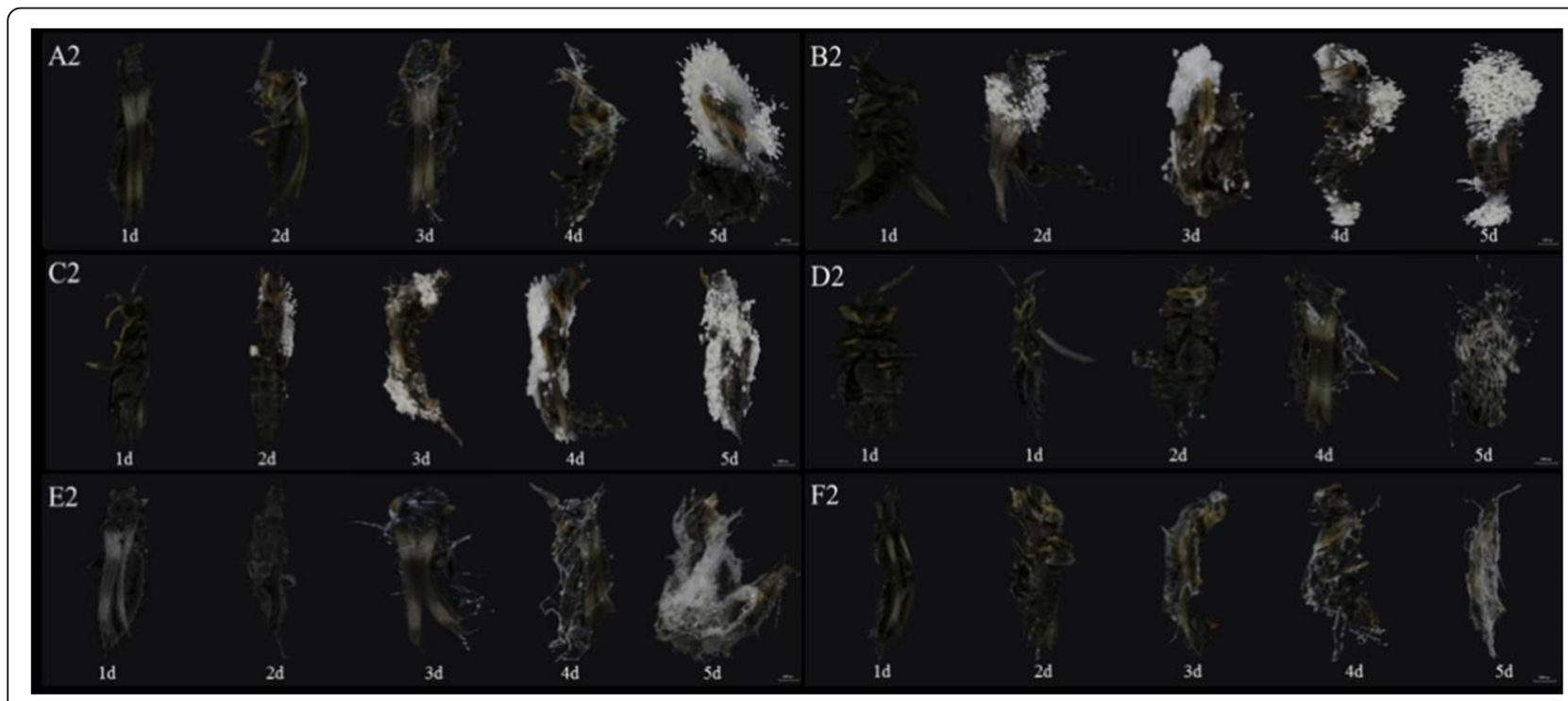

Fig. 5 Images of Megalurothrips usitatus infected with crude extract and observed through a dissecting microscope. A2-F2 Crude extract infected Megalurothrips usitatus at SB009, SB010, SP016, SP535, SCAUDCL-53, and SCAUN-1, respectively 


\section{Microscopic examination}

The 6 fungal isolates induced similar infection symptoms in M. usitatus adults. In the prophase of postinfection, $M$. usitaus' head generated white hyphae, along with the post-infection of time, the hyphae developed continuously around the insects' body white hyphae covered the whole insect body and the activities of insects were abnormal (Fig. 4). However, the insects were treated by crude protein extracts generated hyphae earlier than conidial suspension. Furthermore, the density of hyphae was also higher, following the crude protein extracts application when compared with the application of conidial suspension (Fig. 5).

\section{Conclusion}

Successful isolation and molecular characterization of 6 different strains belonging to 4 fungal species were reported. The pathogenic potential of these isolates was also observed through bioassays of conidial suspension and crude protein extracts against $M$. usitatus adults. $B$. bassiana isolate $\mathrm{SB} 010$ and $A$. attenuatus isolate SCAUDCL-53 were the most effective against $M$. usitatus. These findings will provide baseline information about the screening of effective biological control agents against $M$. usitaus. Further field trials as well as studies on identification of effective fungal toxins are still required to design efficient and environmentally sustainable biopesticides for $M$. usitaus management.

\section{Abbreviations}

A. attenuates: Akanthomyces attenuates; A. aleyrodis: Aschersonia aleyrodis; A. nomius: Aspergillus nomius; B. bassiana: Beauveria bassiana; $C$. fumosorosea: Cordyceps fumosorosea; F. occidentalis: Frankliniella occidentalis: G. ficorum: Gynaikthrips ficorum; ITS: Internal transcribed spacer; I. fumosorosea: Isaria fumosorosea; L. lecanii: Lecanicillium lecanii; $M$. usitatus: Megalurothrips usitatus; PDA: Potato dextrose agar; $\mathrm{LT}_{50}$ : Median lethal time; V. lecanii: Verticillium lecanii

\section{Acknowledgements}

We thank anonymous reviewers and editors for their helpful comments and suggestion of the manuscript.

\section{Authors' contributions}

YB contributed to data curation, data analysis, and writing original draft. CD contributed to data curation, form analysis, and writing original draft. SA contributed to methodology, and writing review and editing. JW contributed to conceptualization, funding acquisition, and supervision; writing the original draft; and writing review and editing. The authors read and approved the final manuscript.

\section{Funding}

This work was financially supported by Key Area Research and Development Program of Guangdong Province (2018B020205003), The Science and Technology Program of Guangzhou, P.R. China (201807010019) and National Natural Science Foundation (31750110475)

\section{Availability of data and materials}

All datasets are presented in the main manuscript.

Ethics approval and consent to participate

Not applicable.
Consent for publication

Not applicable.

\section{Competing interests}

The authors declare that they have no competing interests.

Received: 24 September 2019 Accepted: 24 February 2020

Published online: 01 May 2020

\section{References}

Ainsworth GC, Bisby GR, Kirk PM (2008) Ainsworth \& Bisby's dictionary of the fungi, 5th edn. CABI, Wallingford, p 771

Ali S, Farooqi MA, Sajjad A, Ullah MI, Qureshi AK, Siddique B, Waheed W, Sarfraz M, Asghar A (2018) Compatibility of entomopathogenic fungi and botanical extracts against the wheat aphid, Sitobion avenae (Fab.) (Hemiptera: Aphididae). Egyptian Journal of Biological Pest Control 28:97

Bradford MM (1976) A rapid and sensitive method for the quantification of microgram quantities of protein utilizing the principle of protein dye binding. Annals of Biochemistry 72:248-254

Cafarchia C, latta R, Latrofa MS, Graser Y, Otranto D (2013) Molecular epidemiology, phylogeny and evolution of dermatophytes. Infection, Genetics and Evolution 20:336-351

Diaz PL, Hennell JR, Sucher NJ (2012) Genomic DNA extraction and barcoding of endophytic fungi. Plant DNA fingerprinting and barcoding. Humana Press 1: $171-179$

Du C, Yang B, Wu JH, Ali S (2019) Identification and virulence characterization of two Akanthomyces attenuatus isolates against Megalurothrips usitatus (Thysanoptera: Thripidae). Insects 10:168. https://doi.org/10.3390/ insects 10060168

Elimem M, Harbi A, Limem-Sellemi E, Ben Othmen S, \& Chermiti B (2018) Orius laevigatus (Insecta; Heteroptera) local strain, a promising agent in biological control of Frankliniella occidentalis (Insecta; Thysanoptra) in protected pepper crops in Tunisia. Euro-Mediterranean Journal for Environmental Integration 3-5.

Espinosa PJ, Contreras J, Quinto V, Grávalos C, Fernández E, Bielza P (2005) Metabolic mechanisms of insecticide resistance in the western flower thrips, Frankliniella occidentalis (Pergande). Pest Management Science 61:1009-1015. https://doi.org/10.1002/ps.1069

Faria MR, Wraight SP (2007) Mycoinsecticides and mycoacaricides: a comprehensive list with worldwide coverage and international classification of formulation types. Biological Control 43:237-256

Funk CR, Halisky PM, Johnson MC, Siegel MR, Stewart AV, Ahmad S, Hurley RH, Harvey IC (1983) An endophytic fungus and resistance to sod webworms: association in Lolium Perenne L. Bio/technology 1:189-191

Goloboff PA, Catalano SA (2016) TNT version 1.5, including a full implementation of phylogenetic morphometrics. Cladisitics 32:221-238

Gottel MS, Koike M, Kim JJ, Aiuchi D, Shinya R, Brodeur J (2008) Potential of Leacanicillium spp. for management of insects nematodes and plant diseases. Invertebr Pathol 98:256-261

Immaraju JA, Paine TD, Bethke JA, Robb KL, Newman JP (1992) Western flower thrips (Thysanoptera: Thripidae) resistance to insecticides in coastal California greenhouses. Journal of Economic Entomology 85:9-14

Imoulan A, Alaoui A, Meziane A (2011) Natural occurrence of soil-borne entomopathogenic fungi in the Moroccan Endemic forest of Argania spinose and their pathogenicity to Ceratitis capitata. World Journal of Microbiology and Biotechnology 27:2619-2628

Imoulan A, Wu HJ, Lu WL, Li Y, Li BB, Yand RH, Wand WJ, Wand XJ, Kirk PM, Yao YJ (2016) Beauveria meogensis sp. nov., a new fungus of the entomopathogenic genus from China. J. Invert. Pathol 139:74-81

Jacobson RJ, Chandler D, Fenlon J, Russell KM (2001) Compatibility of Beauveria bassiana (Balsamo) Vuillemin with Amblyseius cucumeris Oudemans (Acarina: Phytoseiidae) to control Frankliniella occidentalis Pergande (Thysanoptera: Thripidae) on cucumber plants. Biocontrol Science and Technology 11:391-400

Kabaluk T, Gazdik K (2005) Directory of microbial pesticides for agricultural crops in OECD countries. Agriculture and Agri-Food Canada 242

Kawasaki M (2011) Verification of a taxonomy of dermatophytes based on mating results and phylogenetic analyses. Medical Mycology 52:291-295

Kumar S, Stecher G, Tamura K (2016) MEGA7: Molecular evolutionary genetics analysis version 7.0 for bigger datasets. Mol. Biol. Evol 33:1870-1874 
Mound LA, Walker AK (1987) Thysanoptera as tropical tramps: new records from New Zealand and the Pacific. New Zealand Entomologist 9:70-85

Muzammil F, Shoaib F (2018) Insecticidal activity of toxic crude proteins secreted by entomopathogenic fungi against Musca domestica L. (Diptera: Muscidae). Kuwait J. Sci 45:64-74

Quesada ME, Carrasco DJA, Santiago A (2006) C. Insecticidal and antifeedant activities of proteins secreted by entomopathogenic fungi against Spodoptera littoralis (Lep. Noctuidae). Journal of Applied Entomology 130:442-452

Rangel DEN, Anderson AJ, Roberts DW (2008) Evaluating physical and nutritional stress during mycelial growth as inducers of tolerance to heat and UV-B radiation in Metarhizium anisopliae conidia. Mycological Research 112:1362-1372

Ravensberg WJ, Malais M, vander Schaaf DA (1990) Verticillium lecanii as a microbial insecticide against glasshouse whitefly ,in Brighton Crop Protection Conference-Pests and Disease British Crop Protection Council. The Lavenham Press Ltd., Lavenham, pp 265-268

Rezende S, Curvello F, Fraga M, Reis R, Castilho A, Agostinho T (2009) Control of the Alphitobius diaperinus (Panzer)(Coleoptera: Tenebrionidae) with entomopathogenic fungi. Revista Brasileira De CiênciaAvícola 11: $121-127$

Saito T, Brownbrideg M (2016) Compatibility of soil-dwelling predators and microbial agents and their efficacy in controlling soil-dwelling stages of western flower thrips Frankliniella occdentalis. Biological Control 92:92-100

SAS TCJ, Gerver WJM, Bruin RD, Mulder PGH, Cole TJ, Wall WD, Hokken-Koelega ACS (2000) Body proportions during 6 years of GH treatment in children with short born small for gestational age participating in a randomised, doubleblind, dose-response trial. Clinical Endocrinology 53:675-681

Schmidt O, Moreth U (2002) Data bank of rDNA-ITS sequences from building-rot fungi for their identification. Wood Science \& Technology 36:429-433

Singh HB, Keswani C, Ray S, Yadav KS, Singh SP, Sarma BK (2015) Beauveria bassiana: biocontrol beyond lepidopteran pests. Soil Biology 43:219-235

Skinner M, Gouli S, Frank CE, Parker BL, Kim JS (2012) Management of Frankliniella occidentalis (Thysanoptera: Thripidae) with granular formulations of entomopathogenic fungi. Biological Control 63:246-252

St Leger RJ, Screen SE, Shams PB (2000) Lack of host specialisation in Aspergillus flavus. Applied and Environmental Microbiology 66:320-324

St Leger RS, Screen S (2001) Prospects for strain improvement of fungal pathogens of insects and weeds. In: Butt TM, Jackson CW, Magan N (eds) Fungi as biocontrol agents progress, problems and potential. CABI Publishing, Wallingford, pp 219-238

Tang LD, Yan KL, Fu BL, Wu JH, Liu K, Lu YY (2015) The life table parameters of Megalurothrips usitatus (Thysanoptera: Thripidae) on four leguminous crops. Florida Entomologist 98:620-625

Ugine TA, Wraight SP, Sanderson JP (2006) Influences of impatiens pollen and exposure to Beauveria bassiana on bionomics of western flower thrips Frankliniella occidentalis. Biological Control 37:186-195

Wang J M (2012) Bionomics and control of potted ficus thrips. (Master Thesis) Agriculture and Forest University, Fuzhou, Fujian, China.

Wright SP, Filotas MJ, Sanderson JP (2016) Comparative efficacy of emulsifiableoil, wettable-powder, and unformulated-powder preparations of Beauveria bassiana against the melon aphid Aphi gossypii. Biocontrol Science and Technology 26:894-914

Zimmermann G (2018) The entomopathogenic fungi Isaria farinosa (formerly Paecilomyces farinosus) and the Isaria fumosorosea species complex (formerly Paecilomyces fumosoroseus): biology, ecology and use in biological control. Biocontrol Science and Technology 18:865-901

Ziółkowska G, Nowakiewicz A, Gnat S, Trościańczyk A, Zięba P, Majer Dziedzic B (2015) Molecular identification and classification of Trichophyton mentagrophytes complex strains isolated from humans and selected animal species. Mycoses 58:119-126. https://doi.org/10.1111/myc.12284

\section{Publisher's Note}

Springer Nature remains neutral with regard to jurisdictional claims in published maps and institutional affiliations.

\section{Submit your manuscript to a SpringerOpen ${ }^{\circ}$ journal and benefit from:}

- Convenient online submission

- Rigorous peer review

- Open access: articles freely available online

- High visibility within the field

- Retaining the copyright to your article

Submit your next manuscript at $\boldsymbol{\nabla}$ springeropen.com 